\title{
Principal Leadership in the Development of Teacher Pedagogical Competence
}

\author{
Bobby Rahmadi \\ Dinas Pendidikan Kabupaten Ogan Komering Ulu \\ e-mail: rahmadibobby@gmail.com \\ Yasir Arafat \\ Universitas PGRI Palembang \\ e-mail: yasirarafat@univpgri-palembang.ac.id \\ Andi Arif Setiawan \\ Universitas PGRI Palembang \\ e-mail: andiarifsetiawan@univpgri-palembang.ac.id \\ Article History: Received on 21 October 2021, Revised on 10 November 2021 \\ Published on 16 November 2021
}

\begin{abstract}
This study described the principal's leadership in guiding teacher pedagogic competence at SMP Negeri 1 Ogan Komering Ulu. This study used a qualitative method where observation, interviews, and documentation used as instruments. The research subjects were principals, teachers and staff. The results of this study indicate that the principal has two leadership styles in empowering and mobilizing teachers and staff. The two styles are charismatic and democratic leadership style. The principal used four models of pedagogical competency development for teachers were supervision, workshops, regular meetings, and the principal directs teachers to participate in educational trainings and seminars. The obstacles were the lack of teacher preparation in making learning tools such as lesson plans and syllabus, the schedule of the principal's activities impromptu so that the implementation of supervision, meetings, or workshops is delayed. There are some teachers who cannot attend meetings or workshops.
\end{abstract}

Keywords: Principal Leadership, Guiding Teacher, Teacher Pedagogical Competence

\section{A. Introduction}

Education is a deliberate and planned effort to create a learning environment and learning process in which students actively develop their potential for religious spiritual strength, selfcontrol, personality, intelligence, noble character, and the skills required by themselves, society, nation, and state (Law No. 20 of 2003). Quality education is critical in order to foster the development of intelligent human beings capable of competing in the globalization era.

Education is defined as a deliberate and systematic effort to motivate, foster, assist, and guide a person in developing all of his potential so that he achieves a higher level of self-esteem (Hikmat, 2009). Through education, the government seeks to educate the Indonesian people. This is in accordance with the goals of Law No. 20 of 2003. The government is doing everything it can improve education, both in terms of quality and quantity, which is the main issue in achieving educational goals. The government's efforts will be futile unless educational institutions work to improve education quality. Improving education quality through 
standardization and professionalization, as is currently being done, necessitates the understanding of various parties to the changes that occur in various components of the education system (Mulyasa, 2019). The role of the leader is one of the determinants of increasing the quality of education in an educational institution.

A leader is someone who can influence subordinates in relation to the tasks that must be completed. Leadership can also be defined as the power or ability to move and influence others (Norkholis, 2006). A group's or institutional organization's leadership is a critical issue. This is due to the fact that the leader is one of the most influential factors in an organization's or institution's success in achieving its goals. Leadership in education refers to all activities undertaken in an attempt to persuade personnel in the educational environment to cooperate and work with full responsibility and sincerity in order to achieve the educational goals that have been established.

Leadership is the process of influencing the activities of an organized group in order to determine/achieve goals (Daryanto, 2011). As the holder of control in educational institutions, the principal plays an important role in the development of educational institutions. The principal serves as a leader in moving school life forward in order to achieve goals. The principal's role is to influence teachers so that they carry out their responsibilities wholeheartedly and enthusiastically. Teachers play an important role in determining the effectiveness of the teaching and learning process as well as the achievement of school goals, so teachers must be able to perform optimally. The influence of the principal's leadership style is inextricably linked to the level of achievement of the teacher's performance.

One of the factors that encourages schools to achieve goals actively and efficiently is principal leadership. The effectiveness of leadership is highly demanded, both for men and women as school principals, as evidenced by the principal's duties and responsibilities (Usman, 2008). Providing guidance to teachers is one of the principal's efforts in advancing schools to perform well. Teacher professionalism is a way of carrying out the task of educating and teaching students that is heavily influenced or determined by the principal's guidance. The guidance is provided so that teachers can carry out their responsibilities in an honest, responsible, effective, and efficient manner.

The principal's role as a leader reflects the principal's responsibility to mobilize all available resources in the school, resulting in a strong work ethic and productivity in meeting objectives. This leadership role is critical because, in addition to being a driving force, it also controls all teacher activities in order to improve teaching professionalism, staff, and students while also investigating problems that arise in the school environment (Wahyosumijo, 2013). The good or bad of a school, as well as its high or low quality, is determined not only by the number of teachers and their skills, but also by the way the principal carries out leadership in his school.

The principal has a significant relationship and influence, specifically between leaders and their subordinates who share the same goal of achieving genuine change (Fitria and Samsiah, 2020). Leaders and subordinates influence each other because they interact democratically to decide what changes they want to make. As a result, the principal's leadership will have a significant impact, if not be decisive, on the school's progress. Because a leader is always in the midst of the members of the organization he leads, the principal's leadership must be of high integrity (Pidarta, 2004). As a result, the principal's leadership is a strategic position in achieving educational goals in modern education. 
A good principal is one who possesses leadership qualities and behaviors that enable him or her to foster a positive school climate and provide high job satisfaction for teachers or their subordinates. In his role as a leader, the principal must be able to direct others to complete the tasks he desires while also being enjoyable for the teachers at work. A good leader is someone who is able to pay attention to the needs and goals of those who work for him, rather than being solely concerned with the power he wields, so that subordinates' job satisfaction is always met, which is group-oriented rather than power-oriented (Handoko, 2000).

The principal is a figure of leadership who is willing to work hard to advance the school and increase the potential of teachers, and who is able to foster and guide teachers, and who must always foster enthusiasm and motivation in order to create harmony between leaders and those being led, thereby improving the quality of work. as a result of which good work performance will be created. Principals must be capable of performing their duties as educators, managers, administrators, supervisors, leaders, innovators, and motivators (Permadi and Arifin, 2010). As a formal leader in the world of education, the principal must be able to carry out his leadership duties, which include knowing, understanding, and understanding all matters relating to school administration management, developing school facilities and infrastructure, and fostering teacher competence.

Teachers play a critical strategic role because their very existence is linked to the success and quality of education (Priansa, 2018). According to Law No. 14 of 2005, a teacher must be professional in the performance of their duties. Professional teachers are those who are skilled in their field. Teacher competence is defined as a teacher's ability to carry out responsibilities responsibly and appropriately (Kusnandar, 2009). Each teacher's competence will demonstrate the teacher's teaching quality (Fathurrohman and Sutikno, 2011).

Teacher competency standards have been fully developed into four main competencies: (a) pedagogic competence, (b) personality competence, (c) professional competence, and (d) social competence. Of course, the four competencies that become the standard of academic qualifications and teacher competencies must be thoroughly mastered by the teacher. Pedagogic competence is one of the competencies that is directly related to readiness to implement learning (Priansa, 2018).

Teacher Pedagogic Competence will result in teachers' ability to design and implement learning strategies that are in accordance with students' competencies, characteristics, and needs in their learning, allowing students to achieve optimal learning integrity and proud achievements. Pedagogic competence is a tangible manifestation of teacher performance in the learning process and field practice. Understanding the characteristics of students, applying various learning methods, providing educational education, communicating empathically and politely, evaluating learning processes and outcomes, and utilizing assessment results for learning purposes are all examples of pedagogic competence. According to the explanation of RI Law No. 14 of 2005, pedagogic competence is defined as the ability to manage student learning.

Ministry of Educational Rule No. 16 of 2007 defines pedagogic competencies as: (1) mastering the physical, moral, spiritual, social, cultural, emotional, and intellectual characteristics of students; (2) mastering learning theory and educational learning principles; (3) developing a curriculum related to the subjects taught; and (4) organizing educational learning; (5) Using information and communication technology for learning purposes; (6) assisting in the 
Volume 2 (2) 2021

E-ISSN: 2723-6919 P-ISSN:2746-0827

development of students' potential to actualize their various potentials; and (7) communicating effectively, empathically, and politely with students. Conducting assessments and evaluations of learning processes and outcomes; (8) Using the assessment and evaluation results for the benefit of learning; and (9) Taking reflective action to improve learning quality.

Pedagogic competence is a reflection of a teacher's fundamental teaching abilities as demonstrated in learning activities. One of the factors that can influence student learning outcomes is mastery of teacher pedagogical competence (Sari, et al, 2015). Teachers must be able to educate students, which necessitates a body of knowledge about how to educate these students as effectively as possible. In practice, however, it does not work as intended. There are still several issues that cause the principal's guidance to be less than optimal.

Ogan Komering Ulu Regency is a district in South Sumatra Province that is home to several educational institutions, including SMPN 1 OKU. Based on observations made at SMP Negeri 1 Ogan Komering Ulu, information was obtained such as (1) the ability of teachers to manage the learning process in the classroom is still lacking, as evidenced by the methods used by teachers in learning that have not been varied; (2) the lack of ability of teachers in preparing lesson plans, such as lesson plans and teaching materials; and (3) the lack of ability of teachers in preparing lesson plans, such as lesson plans and teaching materials; (4) Inequitable distribution of teacher education; and (5) Inadequate guidance provided by school principals to increase teacher competence, particularly teacher pedagogic competence.

These issues can be addressed by involving school principals in the leadership role of fostering teacher pedagogic competence as one of the competencies directly related to the preparation of learning implementation in schools. According to Aminah et al. (2012), 1) principals guide teachers in the process of compiling learning programs such as lesson plans, annual programs, semester programs, and details of the effective week; 2) the principal fosters teachers in the implementation of learning by explaining the material, learning media, learning methods, and learning resources; and 3) school principals foster teacher professional competence improvement by measuring teacher professional competence. According to Rahmiq et al. (2019), the principal of SMA Negeri 1 Darul Imarah employs four models of pedagogic competence development for teachers: 1) supervision; 2) workshops; 3) holding regular school meetings; and 4) seminars, in which the principal directs teachers to participate in educational trainings and seminars. The principal's leadership research in fostering teacher pedagogic competence is important to do based on the description of the problems presented.

\section{B. Methods}

This study is a qualitative descriptive one. The qualitative descriptive method is used to collect and describe in-depth data that has meaning. Meaning is actual data, specific data that has a value hidden behind visible data. As a result, qualitative research places less emphasis on generalization and more emphasis on meaning (Sugiyono, 2019). The researchers focused on describing the principal's leadership in fostering the pedagogic competence of teachers at SMP N 1 Ogan Komering Ulu in this study. The principal and teachers of SMP Negeri 1 Ogan Komering Ulu were the subjects of this study. Teachers and staff/employees at SMP Negeri 1 Ogan Komering Ulu served as informants in this study. Observation techniques, interview techniques, and documentation were used in this study to collect data. In this study, data was analyzed by organizing and selecting data into manageable units, synthesizing it, looking for 
Volume 2 (2) 2021

E-ISSN: 2723-6919 P-ISSN:2746-0827

and discovering patterns, determining what was important and what was learned, and deciding what to tell or tell others.

\section{Results and Discussion}

\section{Principal Leadership in Teacher Pedagogic Competence Development at SMP N 1 Ogan Komering Ulu}

The principal who has a significant influence on his subordinates. The principal of SMP N 1 Ogan Komering Ulu has his own style for mobilizing and developing teachers and staff. Leadership style is a pattern used by a typical leader to influence his subordinates; what he chooses to influence group members forms his leadership style (Wahjosumidjo, 2013). Leadership style refers to a leader's actions that are both visible and invisible to his subordinates.

The principal's leadership style has a significant impact on the level of educational success. The better the leadership style, the easier it is to foster and empower teachers and staff so that educational success is closer; conversely, the less good the leadership style, the more difficult it is to empower and nurture teachers and staff so that educational success is further away.

According to the findings of interviews, observations, and documentation, the principal's leadership style in fostering teacher pedagogic competence at SMP N 1 Ogan Komering Ulu has two leadership styles: charismatic leadership style and democratic leadership style.

In charismatic leadership, the leader possesses extraordinary energy, charm, and the ability to influence others, resulting in a large following and dependable bodyguards. Leaders with this style are typically visionary and enjoy change and challenges. Charisma is classified into two types: natural authority (the authority that already exists in the leader) and artificial authority (the authority that is created by position and power) (Hikmat, 2009).

A person's leadership style is defined by their actions to influence others. The principal of SMP N 1 Ogan Komering Ulu, is well-liked by teachers and staff. Teachers and staff also follow the principal's regulations; for example, the teacher does not leave the school unless the principal gives permission, and unless there is an emergency, the teacher follows these regulations.

Style of Leadership the principal of SMP N 1Ogan Komering Ulu, is a charismatic leader. A charismatic leadership style is one that can entice subordinates to follow the rules established by the principal. Leaders who use this style are respected by their followers.

The principal of SMP N 1 Ogan Komering Ulu is a principal who can be trusted by his subordinates; trust exists between the principal, teachers, and staff. Principals frequently use informal communication when communicating with teachers and staff. Interaction within the school environment is also harmonious, with a strong bond between the teacher and the principal.

The interaction carried out by charismatic leadership is more informal, as it does not need to be formally appointed and is not determined by wealth, age, physical form, and so on. His confidence in him, on the other hand, is very high, and his followers believe in him so wholeheartedly that he is frequently praised and adored (Rahmi, 2014). 
The principal of SMP N 1 Ogan Komering Ulu is well-liked and respected by teachers and staff. According to him, collaboration between teachers and school principals can aid in the achievement of this school's goals. The principal constantly motivates teachers and staff to work harder and supervise every activity that has been assigned in order to achieve good work performance, and the principal also awards teachers who achieve good work performance. The principal always involves teachers and staff in all activities at the school. Every decision made by the principal involves deliberation with teachers and staff, and the principal solicits input and suggestions from subordinates.

The principal of SMP N 1 Ogan Komering Ulu has two leadership styles, namely, a charismatic leadership style that is able to empower subordinates by using informal, harmonious, and familial interactions so that they can be trusted by subordinates and a democratic leadership style that is oriented towards subordinates to work together and achieve common goals.

\section{Teacher Pedagogical Competence Development Model at SMP N 1 Ogan Komering Ulu}

The ability of a teacher to manage learning is referred to as pedagogic competence. In order for the teacher to have the ability, he must properly develop himself, because the teacher's function is to foster and develop students' abilities professionally in the teaching and learning process. As a result, not only teachers, but also school principals, play an important role in fostering teacher competence.

Based on the principal of SMP N 1 Ogan Komering Ulu's interviews, observations, and documentation, four models of teacher pedagogic competence development were used.

\section{a. Supervision Model}

One of the principal's responsibilities is to supervise the work of educational personnel (Mulyasa, 2010). To determine the extent to which teachers are capable of carrying out learning, the principal should conduct supervision activities on a regular basis, which can be done through class visits to directly observe the learning process, particularly in the selection and use of methods, media used, and student involvement in the learning process.

As supervisor, the principal is responsible for providing guidance, assistance, supervision, and assessment on issues related to the technique of implementing and developing teaching education in the form of improvement of teaching education programs and activities in order to create more teaching and learning situations excellent (Indrafachrudi and Tahelele 2006) (Suratman et al, 2020).

The principal of SMP N 1 Ogan Komering Ulu conducts class supervision once a semester, which is carried out by the principal himself unless the principal is unavailable, in which case a vice principal or senior teachers take his place. Prior to supervising the principal, the principal notifies the teacher in question one week in advance, and there is also unexpected supervision without notice.

The principal's supervision activities at SMP N 1 Ogan Komering Ulu are routine activities carried out each semester. This is done with the intention of seeing, reviewing, or researching 
what is done by superiors on the realization of subordinates' activities and work results. The principal of SMP N 1 Ogan Komering Ulu may conduct class visits as part of his supervision. With the goal of assessing teachers' abilities as educators in their respective fields and assisting them in making necessary improvements.

\section{b. Workshop Model}

The principal of SMP N 1 Ogan Komering Ulu frequently meets with teachers to discuss teacher problems; the principal plays a critical role in resolving teacher problems, one of which is competence in managing learning. The principal of SMP N 1 Ogan Komering Ulu also assists in providing general guidance to teachers on the procedures for preparing learning tools, which is specifically carried out by curriculum representatives.

The above statement is consistent with the research of Zulfadewina et al., (2018), who state that workshops in the world of education are activities carried out to develop the ability to think and work together in groups to discuss and solve existing problems, with the goal of improving the quality of pedagogic competence so that teachers can develop lesson plans.

\section{c. School Meeting Procurement Model}

The principal of SMP N 1 Ogan Komering Ulu holds a monthly meeting or routine meeting at the beginning of each month, which is held at the school, and teachers and staff are required to participate or be present. The purpose of this meeting is to discuss teacher responsibilities, school activities, school reports, and teacher and staff issues. For example, the issue of teacher competence in teaching is then addressed collaboratively so that teachers can be more effective teachers.

This is consistent with Susanti et al. (2017) Darmiati et al (2020) research, which found that good principals generally carry out their duties based on the plans that have been prepared. Meetings with teachers will be held on a regular basis as part of the planning.

\section{d. Seminar Model}

SMP N 1 Ogan Komering Ulu's principal has never held a seminar at the school. However, the principal encourages teachers to participate in seminars outside of school, such as in-service activities such as 2013 curriculum training, subject training, guidance on creating learning tools, exemplary teacher tests, computer training, training, MGMP training, workshops, principal candidate tests, and others. The education office organized the seminars and training, and there was also a seminar on the Unsyiah campus. Teachers who take turns must share their knowledge with other teachers after gaining knowledge from training and seminars.

A seminar is a meeting or trial to discuss a problem led by the session's chairman (professor or an expert). Meetings or trials in seminars are typically held to naturally discuss a problem. Those who take part are experts in their respective fields. Meanwhile, participants contribute by submitting questions, reviews, and discussions in order to gain a better understanding of a problem. The class supervision model, the workshop or workshop model, the school meeting procurement model, and the seminar or training model are all used by the principal of SMP N 1 Ogan Komering Ulu to develop teacher pedagogical competence. 


\section{School Principal Constraints in Guiding Teacher Pedagogic Competence at SMP N 1 Ogan Komering Ulu}

According to the findings of research and interviews, there are several barriers to fostering pedagogic competence. The first is a lack of teacher preparation in preparing learning tools, the second is the father's busyness, and the third is during meetings, workshops, or seminars related to teacher competency development. Some teachers are unable to attend due to personal reasons. First, there is a lack of teacher preparation in preparing learning tools; some teachers at SMP N 1 Ogan Komering Ulu are still negligent in preparing learning tools, such as lesson plans and syllabus; this occurs when the principal supervises the class once a semester.

Second, the principal's busyness is something that happens all the time. The principal is an educational leader with a full schedule. The busyness referred to here is a sudden rush that occurs when the principal will supervise the teacher in the classroom, requiring the vice principal to take over supervision (Desrina et al, 2020).

Third, some teachers are less disciplined when it comes to attending meetings or workshops. The principal has stated that teachers are welcome to attend monthly meetings and workshops, but some teachers are unable to attend due to unexpected busyness. There must be a report in advance for teachers who are unable to attend.

\section{Conclusion}

In terms of empowering and mobilizing teachers and staff, the principal of SMP N 1 Ogan Komering Ulu employs two leadership styles. The two types of leadership styles are charismatic leadership and democratic leadership. The principal of SMP N 1 Ogan Komering Ulu employs four models for developing teachers' pedagogical competencies: the supervision model, the workshop model, the school meeting procurement model, and the seminar model. Obstacles to the principal of SMP N 1 Ogan Komering Ulu in fostering teacher pedagogic competence, namely a lack of teacher preparation in creating learning tools such as lesson plans and syllabus, and an impromptu schedule of the principal's activities, which delays the implementation of supervision, meetings, or workshops. Some teachers are unable to attend meetings or workshops.

\section{E. Acknowledgement}

We Thank to Dinas Pendidikan Kabupaten Ogan Komering Ulu, Rector Universitas PGRI Palembang, Director of Graduate Program, the Education Management Study Program and friends who have supported us to do this project.

\section{References}

Aminah., Khairudin., \& Husen. (2012). Pembinaan Kompetensi Profesional Guru Oleh Kepala Sekolah Pada SMP Negeri 2 Kota Sigli [Professional Competence Development of Teachers by the Principal at SMP Negeri 2 Sigli]. Jurnal Administrasi Pendidikan Pascasarjana Universitas Syiah Kuala, 1(1).

Darmiati, D., Kristiawan, M., \& Rohana, R. (2020). The Influence of School Leadership and Work Motivation toward Teacher's Discipline. Journal of Social Work and Science Education, 1(1), 32-44. https://doi.org/10.52690/jswse.v1i1.8 
Daryanto. (2011). Kepala Sekolah sebagai Pemimpin Pembelajaran [Principal as Learning Leader]. Yogyakarta: Gava Media.

Desrina, D., Fitria, H., \& Mulyadi, M. (2020). The Relationship between Principal Supervision and Interpersonal Communication with the Work Ethic of Teachers. Journal of Social Work and Science Education, 1(2), 161-167. https://doi.org/10.52690/jswse.v1i2.45

Fathurrohman, P., \& Sutikno, M. S. (2011). Strategi Belajar Mengajar Melalui Penanaman Konsep Umum dan Konsep Islam [Teaching and Learning Strategies Through Instilling General Concepts and Islamic Concepts]. Bandung: Refika Aditama.

Fitria, H., \& Samsiah. (2020). Peran Kepala Sekolah Dalam Mewujudkan Program Sekolah Adiwiyata [The Principal's Role in Realizing the Adiwiyata School Program]. Jurnal Manajemen, Kepemimpinan, dan Supervisi Pendidikan, 5(2).

Handoko, T. H. (2000). Manajemen Personalia dan Sumber Daya Manusia [Personnel and Human Resources Management]. Yogyakarta: BPFE

Hikmat. (2009). Manajemen Pendidikan [Education Management]. Bandung: Pustaka Setia.

Indrafachrudi, S., \& Tahalele. (2006). Bagaimana Kepemimpinan Kepala Sekolah yang Efektif [How to Effective Principal Leadership]. Malang: Ghalia Indonesia

Kusnandar. (2009). Guru Profesional [Professional Teacher]. Jakarta: Rajawali Pers

Law Number 14 of 2005

Law Number 20 Year 2003

Minister of National Education Regulation No. 16 Year 2007

Mulyasa, E. (2019). Manajemen Kepemimpinan Kepala Sekolah [Principal Leadership Management]. Jakarta: Bumi Aksara

Norkholis. (2006). Manajemen Berbasis Sekolah: Teori, Model, Aplikasi [School Based Management: Theory, Model, Application]. Jakarta: Raja Grafindo Persada

Permadi, D., \& Arifin, D. (2010). Kepemimpinan Transformasional Kepala Sekolah dan Komite Sekolah [Transformational Leadership of Principals and School Committees]. Bandung: Sarana Panca Karsa Nusa

Pidarta, M. (2004). Manajemen Pendidikan Indonesia [Indonesian Education Management]. Jakarta: Rineka Cipta.

Priansa, D. J. (2018). Kinerja dan Profesionalisme Guru [Teacher Performance and Professionalism]. Bandung: Alfabeta 
Volume 2 (2) 2021

E-ISSN: 2723-6919 P-ISSN:2746-0827

Rahmi, S. (2014). Kepemimpinan Transformasional dan Budaya Organisasi [Transformational Leadership and Organizational Culture]. Jakarta: Mitra Wacana Media

Rahmiq., Narussalami., \& Yani, D. (2019). Kepemimpinan Kepala Sekolah Dalam Pembinaan Kompetensi Pedagogik Guru Di SMA Negeri 1 Unggul Darul Imarah Kabupaten Aceh Besar [Principal Leadership in Guiding Teacher Pedagogic Competence at SMA Negeri 1 Unggul Darul Imarah, Aceh Besar District]. HIJRI - Jurnal Manajemen Pendidikan dan Keislaman, 8(1).

Sari, Y. P., Okianna., \& Syahrudin, H. (2015). Pengaruh Kompetensi Pedagogik Guru Terhadap Hasil Belajar Siswa Mata Pelajaran Kewirausahaan Di SMA [The Effect of Teacher's Pedagogic Competence on Student Learning Outcomes of Entrepreneurship Subjects in High School]. Jurnal Pendidikan dan Pembelajaran Khatulistiwa, 4(8).

Sugiyono. (2019). Metode Penelitian Kuantitatif Kualitatif [Qualitative Quantitative Research Methods]. Bandung: Alfabeta

Suratman, S., Arafat, Y., \& Eddy, S. (2020). The Influence of Principal's Leadership and Teacher's Competence toward Teacher's Performance in Indonesia. Journal of Social Work and Science Education, 1(2), 96-104. https://doi.org/10.52690/jswse.v1i2.32

Susanti., Rois., \& Ifriqia. (2017). Kepemimpinan Kepala Sekolah Dalam Meningkatkan Kompetensi Guru [Principal Leadership in Improving Teacher Competence]. Jurnal Edudeena 1(2).

Usman, H. (2008). Manajemen Teori, Praktik, dan Riset Pendidikan [Management Theory, Practice and Educational Research]. Jakarta: Bumi Aksara

Wahjosumidjo. (2013). Kepemimpinan Kepala Sekolah Tinjauan Teoritik dan Permasalahannya [Principal Leadership Theoretical Review and Its Problems]. Jakarta: Raja Grafindo Persada

Zulfadewina., Nurmawati., \& Meilana. (2018). Peningkatan Profesionalisme Pedagogik Mengajar Guru TK, SD, SMP/MTS Melalui Pelatihan Mengajar Gaya Motivator (MGM) [Improving Pedagogic Professionalism in Teaching Kindergarten, Elementary, Junior High School/MTS Teachers through Motivator Style Teaching Training (MGM)]. Jurnal SOLMA, 7(1). 